\title{
A Review of Dissolved Organic Matter Transport Processes Affecting Soil and Environmental Quality
}

\section{S. K. Deb and M. K. Shukla*}

Department of Plant and Environmental Sciences, New Mexico State University, MSC 3Q, P.O. Box 30003, Las Cruces, NM 88003

\begin{abstract}
Dissolved organic matter (DOM) affects several processes in soil and water including nutrient cycling, soil and water pollution and $\mathrm{CO}_{2}$ flux between the soil and atmosphere. The aim of this review is to collate and synthesize the literature on the transport processes of DOM in soil. The DOM normally comprises of only a small fraction of soil organic matter (SOM) and originates mainly from the decomposition and solubilization of SOM, which is accumulated on soil surface or soil profile from plant residues and additions of organic amendments such as animal and poultry manures and other biosolids. The DOM is one of the most reactive and mobile SOM fractions and has a major influence on biogeochemical processes in both terrestrial and aquatic environments. Terrestrially borne DOM is subjected to microbial decomposition, photodegradation and adsorption on soil mineral surfaces. It is sorbed on mineral surfaces and high adsorption capacities of clay minerals and oxides for DOM sorption are demonstrated in laboratory studies. However, these high sorption values are not reproduced in limited field studies. Similarly, a few data available on the transport of DOM through macropores also demonstrate the limited control of sorption on DOM retention in soil profile. Thus, there is a need to further investigate the physical and chemical protection mechanisms, as well as the biodegradability of DOM shown in laboratory studies. There is an increasing need to clearly understand the formation, fate and transport of DOM at field scales. The environmental factors such as precipitation and temperature, land use change, land management, and biological factors have profound and discrete influences on DOM dynamics in soil profile. Future research efforts must focus on the assessment of the influences of these factors by conducting field studies in different climatic zones, soils, and land use and management systems.
\end{abstract}

Keywords: Dissolved organic matter; Dissolved organic carbon; Sorption; Biogeochemical processes; Nutrient cycling; Anion exclusion; Mineralogy; Climate change; Water quality

\section{Introduction}

The importance of soil organic matter (SOM) in supplying nutrients, contributing to cation exchange capacity (CEC), and improving soil structure is well recognized. When in soil solution and pass a filter pore size of $0.4-0.6 \mu \mathrm{m}, \mathrm{SOM}$ is known as dissolved organic matter (DOM) [1,2]. The organic matter in terrestrial and aquatic environments primarily comprises of two operationally defined phases: (i) particulate and (ii) DOM; and both are complex mixtures of many organic compounds and humic substances.

Almost all ecosystems contain DOM and the size of its pool can vary at multiple scales ranging from amino acids to complex high molecular weight SOM. The DOM has an important influence on soil forming processes [3,4], mineral weathering [5], and pollutant transport $[6,7]$. When present in soil solution, DOM plays a vital role in many biogeochemical processes, and transport and fate of several contaminants including heavy metals in soil, surface water and groundwater $[7,8]$. Recycling of elements (i.e., C, N, P and S) in the soil is strongly influenced by DOM. Equally affected is the export of nutrients to surface and groundwater resources. The DOM also influences the transport behavior of pesticides and herbicides through the vadose zone. Several natural systems behave as a three-phase system where contaminants present in the vadose zone are sorbed to soil matrix, sorbed to DOM, or present as a freely dissolved substance. The relative proportion of contaminant in each of the three phases is important and determines the transport behavior, fate and characteristics of the solute with respect to migration and surface and groundwater contamination. For example, according to Carter and Suffet [9], Chiou et al. [10], and Hassett and Milicic [11], DOM increases the solubility and decreases the volatility of certain organic contaminants, and thus increases their transport through the soil profile. Hydrophobic contaminants in natural waters exist in two states, i.e., one that is truly dissolved and one that is bound to DOM [12]. While this binding decreases a hydrophobe's apparent volatility, bioavailability, and attachment to particles and increases its apparent solubility, binding also brings a hydrophobic contaminant into a chemical environment that is distinct from water and thus can affect its reactivity.

Estimates of the impact of DOM on terrestrial C balance mostly rely on the fluxes measured in river waters. The flux of DOM in river water ranges from 1 to $10 \mathrm{~g} \mathrm{C} \mathrm{m}^{-2} \mathrm{y}^{-1}$ for many ecosystems [13]. Therefore, these fluxes are considered a small or insignificant component of the ecosystem $\mathrm{C}$ budget as compared to the $\mathrm{C}$ fluxes associated with primary productivity or heterotrophic respirations in terrestrial ecosystems [14]. However, there are several reasons to believe that DOM fluxes are more important than that suggested by usually small river fluxes. Over time scales ranging from few months to several years, a consistent loss of DOM from the soil profile can reduce the capacity of ecosystems to sustain primary productivity [15]. The DOM fluxes through soil profile can be much larger than the fluxes associated with runoff that eventually ends up in stream water (Table 1 and Table 2). Within a soil profile, DOM dynamics is an important mechanism involved in soil formation. Therefore, it is of great importance to

*Corresponding author: Manoj K. Shukla, Department of plant and Environmental Sciences, New Mexico State University, MSC 3Q, P.O. Box 30003, Las Cruces, NM 88003, Tel: 575-646-2324, Fax: 575-646-6041, E-mail: shuklamk@nmsu.edu

Received October 11, 2011; Accepted November 07, 2011; Published November 09, 2011

Citation: Deb SK, Shukla MK (2011) A Review of Dissolved Organic Matter Transport Processes Affecting Soil and Environmental Quality. J Environment Analytic Toxicol 1:106. doi:10.4172/2161-0525.1000106

Copyright: (C) 2011 Deb SK, et al. This is an open-access article distributed unde the terms of the Creative Commons Attribution License, which permits unrestricted use, distribution, and reproduction in any medium, provided the original author and source are credited. 
Citation: Deb SK, Shukla MK (2011) A Review of Dissolved Organic Matter Transport Processes Affecting Soil and Environmental Quality. J Environment Analytic Toxicol 1:106. doi:10.4172/2161-0525.1000106

Page 2 of 11

\begin{tabular}{|c|c|c|c|}
\hline Measured DOM Concentration $\left(\mathrm{mg} \mathrm{L}^{-1}\right)$ & Horizons & Soil Order & Reference \\
\hline $\begin{array}{l}22 \\
23\end{array}$ & $\begin{array}{l}O \\
A\end{array}$ & Andisol & Dawson et al. (1981) \\
\hline $\begin{array}{l}36 \\
22 \\
10\end{array}$ & \begin{tabular}{|l} 
O \\
BA \\
B \\
\end{tabular} & Ultisol & Dawson et al. (1981) \\
\hline $15-69$ & $<50 \mathrm{~cm}$ & Spodosol & [62] \\
\hline $2-13$ & B & Ultisol & Meyer and Tate (1983) \\
\hline $\begin{array}{l}28.1 \\
5.91 \\
2.96\end{array}$ & $\begin{array}{l}\text { A } \\
\text { Bs } \\
B\end{array}$ & Spodosol & {$[16]$} \\
\hline $\begin{array}{l}10-53 \\
2-12\end{array}$ & $\begin{array}{l}\text { A, B } \\
\text { B, C }\end{array}$ & Spodosol & {$[60]$} \\
\hline \begin{tabular}{|l|}
14 \\
7.4 \\
2.8
\end{tabular} & \begin{tabular}{|l}
$O$ \\
$B$ \\
$B C$
\end{tabular} & Spodosol & Cronan et al. (1990) \\
\hline \begin{tabular}{|l|}
13.7 \\
2.1 \\
0.78 \\
\end{tabular} & $\begin{array}{l}\mathrm{O} \\
\mathrm{Bt} \\
\mathrm{C}\end{array}$ & Ultisol & Cronan et al. (1990) \\
\hline $\begin{array}{l}32.5 \\
32.5\end{array}$ & $\begin{array}{l}\mathrm{O} 1 \\
\mathrm{Oa}\end{array}$ & Inceptisol & [21] \\
\hline
\end{tabular}

Table 1: Measured dissolved organic matter (DOM) concentrations in various soils. Most of the soil solution was collected using tension lysimeters (modified from Herbert and Bertsch [1]).

\begin{tabular}{|c|c|c|c|c|}
\hline \multirow{2}{*}{ Land use/ vegetation cover/Site } & \multicolumn{3}{|l|}{ DOC flux $\left(\mathrm{g} \mathrm{C} \mathrm{m}^{-2} \mathrm{y}^{-1}\right)^{*}$} & \multirow{2}{*}{ Reference } \\
\hline & Surface soil $(0-20 \mathrm{~cm})$ flux & Subsurface soil $(20-100 \mathrm{~cm})$ flux & Stream flux & \\
\hline Eucalyptus forest and grasses, sandy loam, South Australia & 22 & $2-3$ & & Stevens and Cox (1999) \\
\hline Eucalyptus forest and grasses, clay loam, South Australia & $2-5$ & $3-5$ & & Stevens and Cox (1999) \\
\hline Deciduous forest, Coweeta forest, NC & 42 & & & [21] \\
\hline Temperate deciduous forest, Coweeta forest, NC & & & 2 & Meyer and Tate (1983) \\
\hline Hardwood and temperate deciduous forest, Hubbard forest, $\mathrm{NH}$ & 21 & 2 & 2 & [22] \\
\hline Hardwood forest, Harvard forest, MA & 40 & 12 & & [73] \\
\hline Coniferous forest, Harvard forest, MA & 23 & 17 & & [73] \\
\hline Temperate evergreen forest, Westlake, New Zealand & 84 & 18 & 1 & [38] \\
\hline Moss/Fern/Scrub forest, Westlake, New Zealand & 69 & 69 & 42 & [38] \\
\hline Temperate evergreen forest, Bavaria, Germany & $11-17$ & 2 & & Michalzik and Matzner (1999) \\
\hline Tropical evergreen forest, Luquillo LTER, Puerto Rico & & $4-9$ & 3 & McDowell (1998) \\
\hline Tropical evergreen forest, Central Amazon Basin, Brazil & & 2 & & McClain et al. (1997) \\
\hline Tropical flooded forest, Central Amazon Basin, Brazil & & 40 & & McClain et al. (1997) \\
\hline Hardwood forest (Oak), Jutland, Denmark & 26 & 2 & & Nielsen et al. (1999) \\
\hline Coniferous forest (Spruce), Jutland, Denmark & 46 & 14 & & Nielsen et al. (1999) \\
\hline Mixed Pine-Oak forest, Atlantic Plain, SC & 13 & 6 & & [38] \\
\hline
\end{tabular}

*Surface and subsurface soils are usually Oi or Oa, and B horizons, respectively

Table 2: Dissolved organic carbon (DOC) across a range of ecosystems (modified from Neff and Asner [125])

understand the distribution and stabilization of soil $\mathrm{C}$ including the control of activities of microorganisms within a soil profile [16]

The DOM dynamics has been extensively studied in numerous laboratory experiments using disturbed soil samples, but few studies have been conducted under field conditions [17]. Since 1970s, several attempts have been made to understand the behavior and transport dynamics of DOM through the soil profile. Therefore, the objectives of this review are to: (1) collate and synthesize the available information on DOM processes and dynamics, (2) review the biogeochemistry of DOM in the vadose zone, and (3) identify and prioritize future research needs.

\section{Constituents of Dissolved Organic Matter}

The DOM is a complex mixture of numerous organic compounds and humic materials in different proportions. The DOM found in streams, rivers or in soil solution is from plant biomass, litter, humus, roots, amendments applied on land surface, etc. Chemical identification of the constituents of DOM is possible but limited to a small fraction of low molecular weight substances such as organic acids, sugars and amino acids [1]. Most common compounds in DOM are: amino acids, carbohydrates, hydrocarbons, and aliphatic and aromatic acids (Figure 1). A large portion of DOM in soil solution consists of humic substances with average molecular weight of 1,000 [18]. Organic colloidal material with average molecular weights ranging from 2,000 to 100,000 may also be present as humic and lipid aggregates. Operationally, DOM is defined as the organic molecules of different sizes that pass through a filter of $0.2 \mu \mathrm{m}$ or $0.45 \mu \mathrm{m}[18,19]$. A $0.2 \mu \mathrm{m}$ filter is used when some organic or inorganic colloidal materials is present (i.e., organic particulates), which can pass through $0.45 \mu \mathrm{m}$ filter. Major structural components in freshwater DOM include carboxyl-rich alicyclic molecules (CRAM), heteropolysaccharides, and aromatic compounds [20], which are consistent with components identified in marine DOM [21]. As suggested by Lam et al. [20], the bulk of freshwater DOM is aliphatic in nature, with CRAM derived from cyclic terpenoids as well as material derived from linear terpenoids. 


\section{Origin of Dissolved Organic Matter}

Despite several studies undertaken since 1970s, origin of DOM is still not very clear and contradictory accounts exist in the literature. McDowell and Likens [22] and Zsolnay [2] propose that humified organic matter or leaching and microbial decay of humus is largely responsible for the DOM production in soil. This argument is mainly due to the presence of relatively high proportion of humus than litter in the soil. In contrast, Qualls and Haines [23] have reported high amounts of simple sugars and nonhumic-bound polysaccharides in DOM solutions and thus proposed a high contribution of recent litterfall in DOM production. The Qualls and Haines's [23] argument was supported by Qualls et al. [24] for a deciduous forest ecosystem where highest increases in DOM fluxes were reported in the upper part of forest floor or litter layer. As reviewed by Kalbitz et al. [17], there remains a considerable discussion and uncertainty in the literature regarding the importance of fresh versus older SOM as sources of DOC in forest floor soil solution. While studies on the chemical composition of DOM (e.g., [25]) suggest that most DOM is an end product of the microbial metabolism, the fresh litter also contributes significantly to the production of DOC [26].

Ultimately, as stated by McDowell [27], the source of virtually all DOM in soils is photosynthesis, which includes both recent photosynthate (throughfall, leaf litter, root exudates, decaying fine roots) and the leaching or decomposition of older, microbially processed SOM. As DOM ranges in age from hours to days, up to decades to thousands of years, the range of sources can be equally varied [27-29].

\section{Measurement of Dissolved Organic Matter}

The DOM fluxes have been measured in rivers, streams, ponds, lakes and in the soil profile [13]. Most studies are carried out on discrete catchments ranging in size from 1 to $50 \mathrm{~km}^{2}$. The concentrations of DOM and other nutrients and chemicals are measured both at upstream and downstream levels and effects due to land use and management are assessed by the comparisons of paired catchments [30]. Some other approaches to measuring DOM include: (i) assessment of total DOM or nutrient export by analyzing water samples collected at the lower reaches of a river or catchment [31,32], and (ii) collecting and analyzing samples from representative sections of an entire river system [33-35]. Most of the samples collected from rivers can be termed as instantaneous grab samples. The frequency of water sampling mostly depends on the size of catchment and varies from twice daily, daily, biweekly, weekly, bi-monthly, monthly to event basis (i.e., during high or low flows). Number of samples can also increase with increase in river flow $[22,36]$.

DOM solutions in soils are collected using a number of devices. For laboratory studies, DOM is extracted using centrifuges in batch experiment studies or effluent solution is collected from the bottom of soil columns. Some laboratory column studies also employ suction cups for DOM collection. McDowell et al. [37] evaluated the comparability and reproducibility of batch, kinetic and bioreactor methods to measure biodegradable fraction of dissolved organic C (BDOC) for solutions from a variety of terrestrial sources such as throughfall, soil solution and soil extracts. Their results suggested that the precision of various BDOC methods was similar (5-15\%) across a broad range of BDOC (12-56\% of DOC) [37]. For fields, which are not tiled, several devices can be installed to collect leachate from vadose zone. Some of these devices are: suction cups, piezometers, sampling wells, and tension or zero tension lysimetry $[22,38,39]$. In tile drained fields, samples can be collected on a flow proportional basis or volume average basis. In general, quality of collected solution sample depends upon the device used and, therefore, results also often technique dependent. A comparison of DOC concentrations in soil solutions using a tensionfree collector, a tension Prenart collector and a tension Rhizon collector sampling methods was made over a range of soil types [40]. The DOC concentrations in soil solutions were significantly higher with tensionfree collectors than with tension devices. The lower concentrations obtained with the tension devices were more likely due to artifacts associated with sorptive removal of DOC by the collector or with localized soil compaction induced by the applied vacuum, as well as the influence of tension on the source of soil water from different pores [40]. Tension-free collectors were more representative of free-flowing water through the organic horizon, which is the key to representing DOC fluxes through topsoils.

Chantigny et al. [41] presented the general procedures for collection and analysis of soil DOM, including selected procedures for analyzing $\mathrm{C}$ and $\mathrm{N}$ concentration, key spectroscopic and chemical properties, and biodegradability. Different extraction procedures can result in different DOM samples. As suggested by Zsolnay [42], even minor alterations in extraction protocols can have a serious impact on DOM yield. Understanding the phase distribution of different contaminants in aquatic systems is necessary to determine which factors regulate binding of these contaminants to DOM. The feasibility of solid phase extraction (SPE) and stir bar sorptive extraction (SBSE) for the determination of eight polycyclic aromatic hydrocarbons (PAHs) in run-off water samples was evaluated by García-Falcón et al. [43]. Both the SPE and SBSE were appropriate to determine PAHs in run-off waters. While the SPE was suitable for the determination of overall PAHs, the SBSE was used for the determination of free PAHs. The combination of both extraction techniques could be used to estimate PAHs bound to DOM. Once the fraction percentage the free concentration represented was estimated, the only use of SBSE

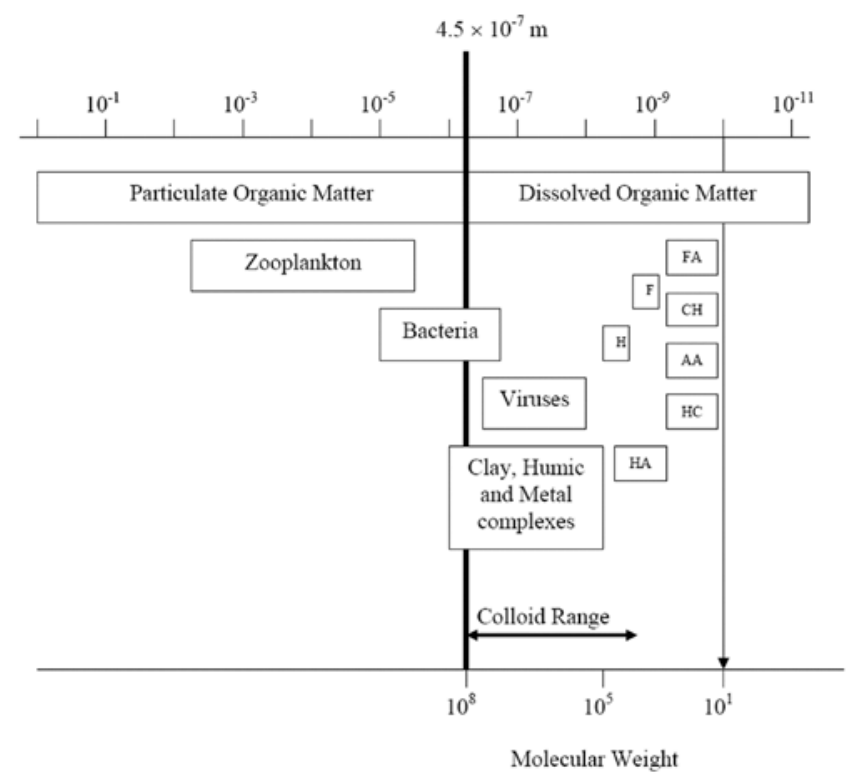

Figure 1: Size range of various carbon compounds in natural waters. F: Fulvic acid, $\mathrm{H}$ : Humic acid, FA: Fatty acid, CH: Carbohydrate, AA: Amino acids, HA Hydrophilic acids, HC: Hydrocarbons (modified from Thurman [18]; Hope et al. [13]) 
was proposed for the estimation of all PAHs fractions (free, bound to DOM, and overall). The determination of PAHs in peat samples is complicated due to the high content of organic matter in peat, which affects both extraction efficiency and analytical quality [44]. Rey-Salgueiro et al. [44] reviewed and addressed the most relevant analytical methods for determining PAHs in peat, as well as evaluated three different extraction procedures, such as ultrasound-assisted solvent extraction (UASE), shaking and pressurized liquid extraction (PLE). The UASE extraction method using hexane:dichloromethane (80:20) as extractant was robust enough to determine the selected PAHs in peat samples. As suggested by Salgueiro et al. [44], the UASE did not demand sophisticated equipment and long extraction times. In contrast, the PLE involved sophisticated equipment and showed important variations in the results.

\section{Processes Affecting Dissolved Organic Matter Fluxes}

The processes associated with DOM fluxes can be subdivided into several categories: (i) atmospheric deposition and production of C, (ii) seasonal effects, (iii) climate and geology, (iv) transport and export to streams or groundwater, and (v) adsorption and storage in the vadose zone [13].

\section{Seasonal effects and geology}

Atmospheric inputs of DOM consisting of both dissolved organic $\mathrm{C}$ and dissolved inorganic $\mathrm{C}$ are low. The concentration of DOM in precipitation ranges between 1 and $10 \mathrm{ppm}[18,45]$ and is usually small compared to internal fluxes. However, some studies have reported concentrations in atmospheric deposition being equal to or more than those in the exported effluent $[22,46]$. Concentrations of dissolved inorganic C (DIC) in precipitation are generally very small $[47,48]$.

Temperature and precipitation affect the production of allochthonous and autochthonous organic C. Several studies have reported high maxima for DOM concentrations in soil solution and $\mathrm{CO}_{2}$ levels in soil air during summer [16,49-52]. Climate and geology have major influence on DOM export through a catchment. Climate impacts primary production and decomposition rates of DOM. In arctic, alpine and arid regions of the world, DOM productivity and export are lower than those in tropical and temperate regions. The terrestrial export of DOM varies with land use under the influence of climatic variability [53]. Climate and vegetation have important role on surface runoff and soil erosion whereas geology has major influence on geomorphology and rates of physical and chemical weathering $[34,54,55]$.

\section{Transport to streams or groundwater}

As precipitation falls through the canopies, on to the forest floor and soil surface, concentration of DOM progressively increases [16,38]. The part of DOM runs off as overland flow towards a ditch or a stream and remaining water infiltrates into soil. During the overland flow, part of DOM is lost to depressional storage, adsorption to soil particles, and interception due to vegetation (Figure 2). All these processes reduce the concentration of DOM in overland flow. The concentration of DOM increases as the infiltrating water moves through the soil profile. DOM is leached in the soil profile and is either stored in the deeper soil profile, adsorbed in the soil or joined to the shallow groundwater. A part of infiltrated DOM can also move laterally and join the open ditch or stream. The role of surface water-groundwater interfaces in the retention and transport of DOM appears highly variable and remains challenging at different scales (i.e., from stream reach scale to the regional and global scales) [56].
Mobility of agrochemicals particularly pesticides in soils plays an important role in the fate and transport of contaminants. A comprehensive review about the mobility and degradation of pesticides in soils and the pollution of groundwater resources was provided by Arias-Estévez [57]. The influence of organic matter and clay contents on the sorption/desorption and degradation of pesticides and their access to groundwater and surface waters were discussed. As described by Arias-Estévez [57], the processes, which directly control the transport of pesticides within the soil and their transfer from the soil to water, include a variety of complex dynamic physical, chemical and biological processes including sorption-desorption, volatilization, chemical and biological degradation, uptake by plants, run-off, and leaching. While the relative importance of these governing processes varies with the chemical nature of the pesticides and the properties of the soil, the degradation and sorption processes are crucial.

\section{Physical and chemical processes in the soil}

The origin and production of terrestrial $\mathrm{C}$ is derived from vegetation and soil. Inputs from vegetation are from biomass, which consists of shoot, fruit, leaf and roots. It can also be from the leaching of $\mathrm{C}$ from live vegetation and litter. Inputs from soil are from SOM, root exudation, microbial metabolism, and erosion and leaching of SOM [18]. DOM concentrations measured in the vadose zone are the net result of processes that remove and/or release DOM. The process that remove DOM from soil solution are adsorption or decomposition and the processes that release DOM are the leaching from litter, organic wastes or desorption from solid phase (Figure 3). This physical and chemical alteration of SOM and the formation of soluble humic substances are generally assumed to be dominated by biota. However, several reports have indicated that the DOM concentrations in soil solutions are mainly controlled by abiotic processes such as desorption, and dissolution from the pool of potential DOM $[58,59]$.

\section{Transport through the soil profile}

A number of studies have been conducted on the fate of DOM during transport through soil profile. Several studies have reported a

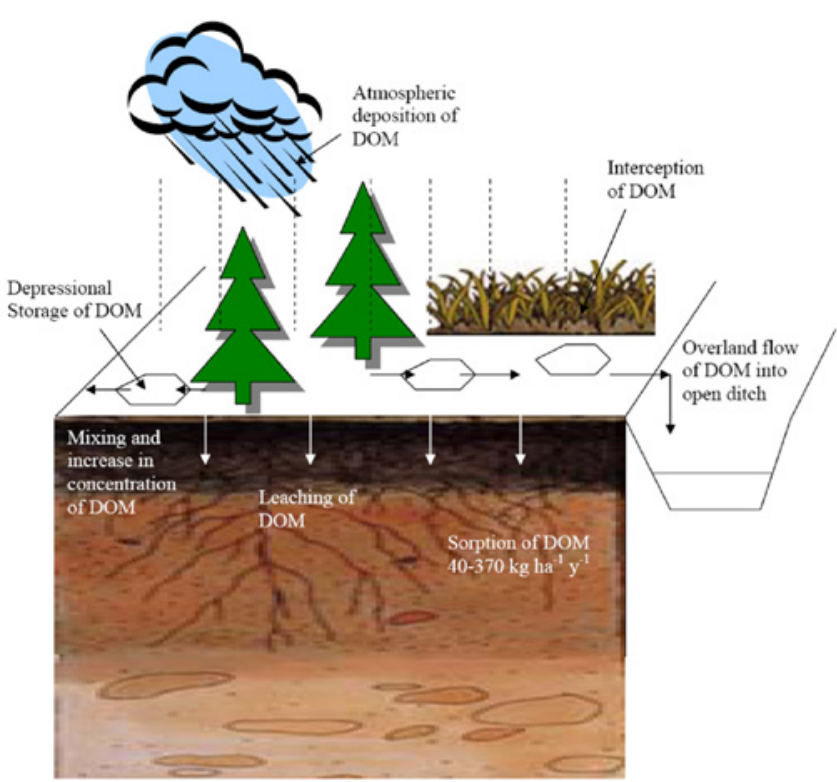

Figure 2: Processes associated with dissolved organic matter (DOM) movement. 
Citation: Deb SK, Shukla MK (2011) A Review of Dissolved Organic Matter Transport Processes Affecting Soil and Environmental Quality. J Environment Analytic Toxicol 1:106. doi:10.4172/2161-0525.1000106

decrease in DOM concentrations and fluxes as water flows through the soil profile largely due to the sorption of organic acids in the B horizon, which occurs as part of podzolization process $[16,18,60]$. Sorption is often the primary cause for declining DOM concentration in soil profile of forested watersheds $[3,16,22,38,60-62]$. Similar observations for a grass land system have been reported by Hornung et al. [63].

Forest soils receive high inputs of PAHs (and other organic contaminants) because of the large intercepting surface constituted by foliage that eventually falls and contributes to the accumulation of PAHs in the soil organic layer [64,65]. García-Falcón et al. [66] studied the levels of eight representative PAHs in the 1-5 cm layer of a periurban woodland soil, which had undergone wildfire and compared with those measured in nearby and distant unburnt periurban woodland soils and in a distant unburnt rural woodland soil. García-Falcón et al. [66] reported that PAH levels at the burnt site fell along the months as the result of rainfall and the prevention of further input from the atmosphere by the overlying layer of wood ash with a very high PAH adsorption capacity, which did not itself appear to act as a source of PAHs. García-Falcón et al. [66] concluded that PAH transport may have been assisted by increased mobilization of PAHs associated with DOM due to an increase in soil $\mathrm{pH}$ caused by the leaching of alkaline ash components from ash.

The primary controls for potential and actual DOM concentration are biotic and abiotic in nature. The DOM concentrations in soil profile are primarily biotically controlled with favorable temperature changes increasing the mineralization in soil profile. However, biotic influences can be masked by the variations in pore water velocity through soil profile and may become more important with increasing time scales [17]. The DOM pool can be further divided into mobile and immobile fractions. Such a classification is mainly based on the pore size distribution of soil matrix $[2,67]$. The portion of DOM present in micropores is immobile and can interact with the mobile fraction by diffusion. On the other hand, DOM associated with macro and mesopores is mobile and is subjected to convective as well as dispersive transport through soil profile [17].

\section{Immobilization}

Limited research has been carried out to quantify the impact of soil properties in DOM immobilization. The DOM consists of both hydrophilic and hydrophobic substances, but the potential for sorption in the vadose zone differs. The hydrophobic DOM generally has higher affinity for soils than hydrophilic [68]. The DOM can be immobilized in soil through complex interactions with the mineral surfaces $[69,70]$. Immobilized $\mathrm{C}$ may be stored within the B horizon for several hundred years [22,38]. The capacity of soil to adsorb DOM is related to the soil $\mathrm{pH}$, mineralogy, antecedent SOM content and amount of $\mathrm{Fe}$ and $\mathrm{Al}$ oxides in the soil. The DOM sorption on mineral surfaces is strongly $\mathrm{pH}$ dependent, with higher sorption observed at lower $\mathrm{pH}$ [71]. Smaller reductions in DOM with depth are observed in peat soils than mineral soils because of the high antecedent soil organic carbon (SOC) concentration $[50,51,72]$. It is mostly assumed that adsorption of DOM on mineral surfaces is far more pronounced than reduction of DOM due to the decomposition [17]. Approximately 40-370 $\mathrm{kg}^{\mathrm{DOM} \mathrm{ha}} \mathrm{y}^{-1}$ is retained in mineral subsoil with sorption being the dominant process of stabilization $[73,74]$.

Gibbsite, especially near $\mathrm{pH} 5$, has the potential to absorb large amounts of fulvic and humic acids from lake sediments [75]. Some other studies have shown that appreciable amounts of DOM can be absorbed on a variety of synthetic Fe oxides and hydroxides $[70,76]$.
Phyllosilicates can also absorb a significant amount of DOM [77,78]. Tipping [79] reported greater adsorption potential for higher than lower molecular weight humic substances in some studies with lab synthesized goethite, hematite, and amorphous Fe gels.

\section{Mechanisms of Sorption}

Mechanisms of DOM immobilization with mineral surfaces are not clearly understood and mostly hypothetical in nature [71] Anion sorption, ligand exchange, protonation, hydrogen bonding, cation bridging, and physical adsorption are some of the mechanisms responsible for the DOM sorption on mineral surfaces [80].

\section{Physical Adsorption}

The adsorption of DOM on mineral surfaces is related to the antecedent SOM content and mineralogy of soil. Jardine et al. [71] reported that large amount of DOM (50 to $70 \%$ ) is retained by crystalline and noncrystalline $\mathrm{Fe}$ oxides and hydroxides from the soil with phyllosilicates, in the less than $2 \mu \mathrm{m}$ clay fraction, accounting for the remaining DOM. Jardine et al. [71] observed that kaolinite, which had lower CEC than illite, exhibited a higher adsorption capacity than illite. With removal of Fe oxides and hydroxides from a soil, a significant reduction in the amount of DOM sorption is observed. The $\mathrm{Fe}$ minerals in the soil are basically hematite $\left(\alpha-\mathrm{Fe}_{2} \mathrm{O}_{3}\right)$ and maghemite $\left(\gamma-\mathrm{Fe}_{2} \mathrm{O}_{3}\right)$ and their abundance increases with depth which is in accord with the increasing DOM sorption with depth. Adsorption of humic acids by hematite was also reported by Tipping [79] and Ho and Miller [81].

The sorptive protection of DOM in soil is primarily indicated by the positive relationships between clay content and SOM [82]. Further evidence is given by the close relationships between DOM and BET surface areas in subsoil horizons [83]. The adsorption hypothesis was further supported by the positive correlations that exist between surface area and SOC contents for sediment samples [84,85]. Soil samples, collected from the A horizons of sixteen states across US, were analyzed for BET specific surface area and SOC content. A linear relationship exists between specific surface area and SOC across a range of soil types (Figure 4) [83].

The contribution of clay minerals on the adsorption of DOM can be assessed by either using pure minerals such as kaolinite and gibbsite or treating the soil with citrate-bicarbonate buffer and sodium dithionite to remove the iron oxides. As much as 250 to $600 \mathrm{mg} \mathrm{kg}^{-1}$ of DOM can

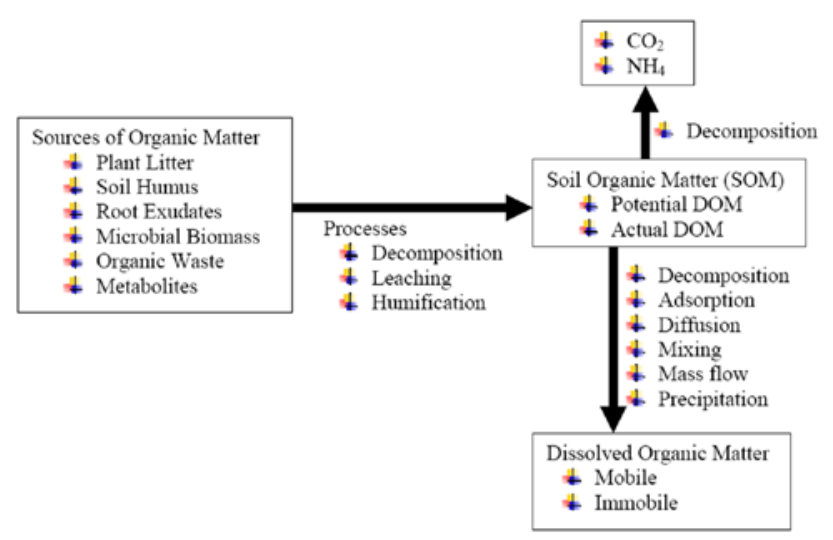

Figure 3: Flow chart for the processes leading to dissolved organic matte (DOM) formation (modified from Kalbitz et al. [17]) 
Citation: Deb SK, Shukla MK (2011) A Review of Dissolved Organic Matter Transport Processes Affecting Soil and Environmental Quality. J Environment Analytic Toxicol 1:106. doi:10.4172/2161-0525.1000106

be adsorbed on a fine loamy soil with Fe oxide removed, 700 to 2100 $\mathrm{mg} \mathrm{kg}^{-1}$ on kaolinite and 700 to $1900 \mathrm{mg} \mathrm{kg}^{-1}$ in gibbsite [71]. Thus, clay minerals play an important role in the adsorption of DOM. Significant adsorption of DOM on gibbsite and kaolinite was also reported by Parfitt et al. [86] and Davis [77]. There can also be other potential adsorbents such as high activity (2:1) clay minerals [87]. In contrast, Jardine et al. [71] reported that 2:1 phyllosilicate illite adsorbed $85 \%$ less DOM than kaolinite.

Degradation of sorbed DOM on surfaces already occupied by SOM is generally more and the sorptive stabilization mainly limited to juvenile mineral surface [74]. In general, DOM sorption on mineral soil results in stabilization [88]. The main mechanisms for stabilization include the selective sorption of intrinsically stable compounds and strong chemical bonds to the mineral soil. Stabilization is also the result of physical protection and inaccessibility of SOM to microorganisms. However, stability of DOM is largest for molecules that adsorb on juvenile mineral surfaces [89]. Surface $\mathrm{OH}^{-}$in gibbsite, goethite, and imogolite is replaced by carboxyl groups of fulvic and humic acid [86]. Humic substances are responsible for ligand exchange of water and surface $\mathrm{OH}^{-}$from $\mathrm{Fe}$ oxides [79]. Kodama and Schinitzer [90] proposed that surface water in sepolite is displaced through a nonionic hydrophobic adsorption mechanism.

The adsorption and desorption of agrochemicals in crop soils govern their fate. Although organic matter is the universal soil colloid that binds most herbicides, metallic hydrous oxides might also have some influence [91] studied the adsorption-desorption of three quaternary ammonium herbicides, i.e., paraquat (PQ), diquat (DQ) and difenzoquat (DFQ), on soils with different chemical-physical characteristics using a batch equilibration method before and after the following sequential selective dissolution procedures: removal of organic matter, and removal of organic matter plus free iron oxides. The adsorption on soils (based on the herbicide soil/solution distribution coefficients) was in the following order: $\mathrm{PQ}>\mathrm{DQ} \geq \mathrm{DFQ}$ [91] concluded that the removal of organic matter from soils seems to leave free new adsorption sites for quats on the clay surface, which is no longer occluded by organic matter. As reported by [91], the amount and nature of the clay surface that remains available after the removal of single soil constituents is a critical parameter in determining the sorptive behavior of cationic contaminants.

\section{Anion Exchange}

Anion exchange reaction involving adsorption of inorganic anions by hydrous oxides is also known as non-specific adsorption [92]. Terms specific and nonspecific are also used to distinguish adsorption due to polar and nonpolar van der Waals forces. Below a $\mathrm{pH}$ of 8 , aluminium and iron hydroxides generally have positive sites. Therefore, coulombic attraction causes organic anions to be attached to oxide surfaces (Figure 5). However, the adsorbed organic anion can also be exchanged with chloride or nitrate $[69,93]$.

Anion exchange mechanism is operative during the adsorption of DOM on allophane as well as on mineral surfaces $[71,80,87]$. Anions such as sulfate and phosphate present in soil solutions complete with DOM for adsorption $[79,80]$. Contrary accounts are available about the affinity of DOM for soil as compared with sulfate. Kaiser and Zech [94] reported that DOM exhibits greater affinity for soil than sulfate while Jardine et al. [71] reported greater affinity of DOM for sulfate than soil. In contrast, Vance and David [95] and David and Zech [96] concluded that it is not clear whether sulfate and DOM compete for the same sites. Sulfate anions have strong electrostatic interactions with positive sites associated with soil and do not induce ligand exchange reactions where surface $\mathrm{OH}^{-}$groups are replaced. In a study on sulfate adsorption on a kaolinite, it has been shown that the ligand exchange is not operative [97]. The contribution of anion exchange during DOM adsorption on a fine loamy (Paleudult) soil was also reported by Jardine et al. [71] who observed that as the concentration of sulfate is increased DOM adsorption in the soil is decreased. This is possible because sulfate eliminates all anion exchange reactions of DOM. In contrast, Vance and David [80] observed that DOM has greater affinity for soil than sulfate as presence of DOM in solution reduces the amount of sulfate adsorbed especially in spodosols soil horizons. Gobran and Nielson [98] also reported competition between DOM and sulfate for exchange sites and reported no sulfate sorption until sulfate concentration exceeded $15.6 \mathrm{mmol} \mathrm{L}^{-1}$.

\section{Ligand Exchange}

In addition to the anion exchange reactions, specific adsorption of anion by hydrous iron and aluminium oxides and kaolinite takes place (Figure 6). This reaction takes place when the anion penetrates the coordination shell of an aluminium or iron atom in hydroxide surface and gets incorporated with the surface hydroxyl layer [92]. Unlike

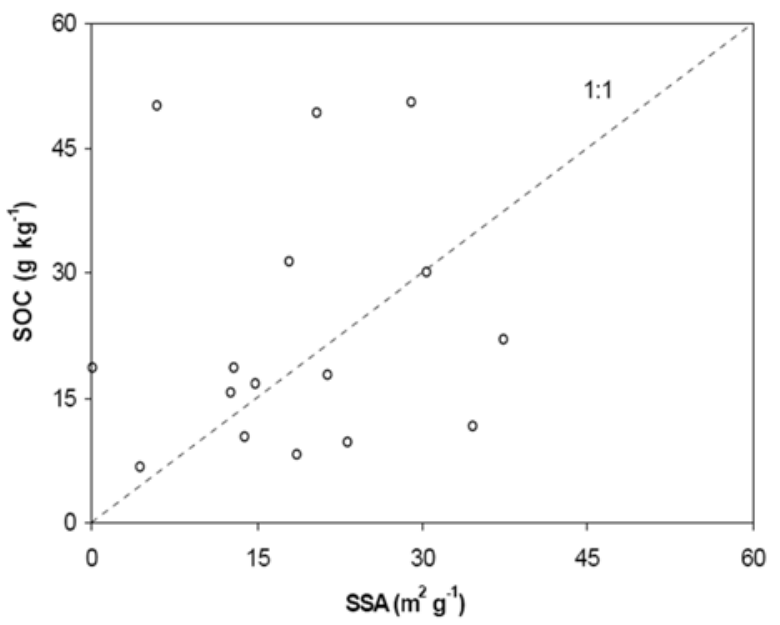

Figure 4: Relationship between BET specific surface area (SSA) and soil organic carbon concentration (SOC) for soil samples collected from 16 states across the United States for 12 different soil types (drawn according to data reported by Mayer [83])

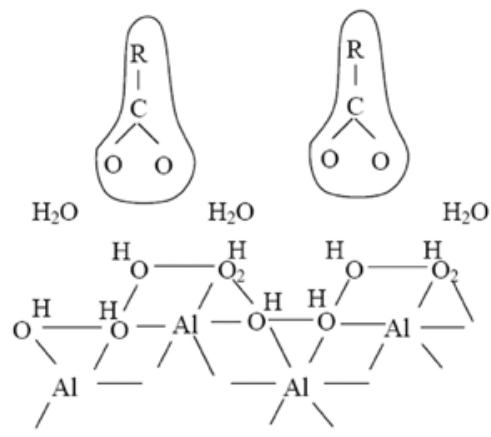

Figure 5: Anion exchange mechanism for interaction of humic acids with hydrous aluminum oxide surfaces. Note: $R$ is the remainder of humic molecules which can also be associated with the surface, $\mathrm{O}$ is oxygen ion, $\mathrm{H}$ is hydrogen ion and $\mathrm{C}$ is clay. (redrawn from Greenland [69]). 
Citation: Deb SK, Shukla MK (2011) A Review of Dissolved Organic Matter Transport Processes Affecting Soil and Environmental Quality. J Environment Analytic Toxicol 1:106. doi:10.4172/2161-0525.1000106

Page 7 of 11

anion exchange reactions, the incorporated anion in a ligand exchange reaction cannot be displaced by leaching with a non-specifically adsorbed anion [92].

\section{Protonation}

The organic molecules of basic amino groups can accept a proton from clay surface and may become cationic after adsorption at the clay mineral surfaces. Such a phenomenon is known as protonation [99]. Some of the factors influencing the ability of clay surface to donate protons are: nature of minerals and exchangeable cations, and water content of mineral. The hydrolysis of water associated with exchangeable metal cations $(\mathrm{M})$ is given by the following reaction:

$$
\mathrm{M}\left(\mathrm{H}_{2} \mathrm{O}\right)_{\mathrm{x}}^{+\mathrm{n}}=\left[\mathrm{M}\left(\left(\mathrm{H}_{2} \mathrm{O}\right)_{\mathrm{X}-1}\right) \mathrm{OH}\right]^{\mathrm{n}-1}+\mathrm{H}^{+}
$$

where $\mathrm{n}$ is positive charge of the hydrated cation. A hydrated $\mathrm{Al}^{3+}$ is a better proton donor than hydrated $\mathrm{Na}^{+}$. The reaction goes to the right as charge to radius ratios increases or water content decreases $[99,100]$.

\section{Hydrogen Bonding}

Hydrogen bonding is an important mechanism of clay mineral and organic interaction. It can happen in two ways. A polar organic molecule forms a hydrogen bond directly with water because it cannot displace a water molecule solving a metal exchange cation [99]:<smiles></smiles>

The other type of $\mathrm{H}$-bonding takes place between an organic cation on an exchange site and another organic molecule:

The proton may also be shared equally between the two amines and the H-bond will be symmetrical. Such type of bond is found on clay surfaces for certain amines, amides, and urea [101].<smiles></smiles>

\section{Precipitation}

Precipitation is another mechanism, which influences the retention or immobilization of DOM in soil horizons. Precipitation of DOM may also contribute to the formation of stable SOM. However, this mechanism has not been investigated in details [88].

\section{Global Flux}

The oceans contain some 50 times as much carbon dioxide as the atmosphere, and small changes in the ocean carbon cycle can therefore have large atmospheric consequences. Various agencies have tried to estimate the DOM fluxes in rivers and those entering in to the ocean. The RiOMar (River-dominated Ocean Margins) workshop reported that estimates for the global flux of atmospheric $\mathrm{C}$ transported by rivers ranged between $500-700 \mathrm{Tg}^{-1}$, of which approximately $35 \%$ is DOC, $20 \%$ particulate organic C (POC) and 45\% DIC [102]. As reported by RiOMar [102], estimates of the particulate and dissolved fractions of riverine organic $\mathrm{C}$ ranged over a factor of $2-3$, but global average values at POC/DOC ratios of $\sim 1\left(\sim 250 \mathrm{Tg}^{-1}\right.$ each $)$. According to the estimates of the Committee on Flux of Carbon to the Ocean 1981, about 50\% of all global DOM entering in rivers ends up in the ocean. About $15 \%$ of total DOM in rivers is oxidized and $25 \%$ is stored in as particulate organic matter (POM) and never reaches the oceans. The total DOM export to the oceans by rivers can be estimated by extrapolating the annual $\mathrm{C}$ flux data from each river around the globe and are presented in Table 3 [13]. The total global $\mathrm{C}$ flux in the world is reported to vary from $0.3 \times 10^{11} \mathrm{~kg} \mathrm{C}^{-1}$ to $10.0 \times 10^{11} \mathrm{~kg} \mathrm{C}^{-1}$ [103-105]. The estimates of global C fluxes are 3 to 10 times smaller than the rate of increase in atmospheric $\mathrm{CO}_{2}$, which is reported to range from 1.8 to $4.7 \times 10^{12} \mathrm{~kg}$ $C \mathrm{y}^{-1}[106]$.

The role of continental erosion in the global $\mathrm{C}$ cycle and its influence on river $\mathrm{C}$ fluxes may change with changing climate particularly between glacial and interglacial cycles [107]. Future global warming may cause significant shifts in rainfall patterns and storm intensities [108], which in turn will directly affect the export of C from terrestrial environments.

\section{Dissolved Organic Matter and Colloidal Transport}

The fate and transport of colloids and associated anions can be strongly influenced by DOM [109]. DOM in soil is composed of humic and fulvic acids and is $\mathrm{pH}$-dependent. Numerous studies have demonstrated that even small amounts of DOM increase the mobility of colloid-associated contaminants (e.g., phosphorus, hydrophobic organic compounds, radionuclide plutonium, agrochemicals, carbon nanotubes, lead, etc.) and colloid-sized pathogens through the hydrologic pathways [109-116]. Laboratory batch kinetic and isotherm experiments have demonstrated that DOM can increase the stability of colloid and nanoparticle suspensions and can facilitate the colloid

\begin{tabular}{|l|l|}
\hline Reference & Organic C flux $\left(\times 10^{8} \mathrm{Mg} \mathrm{C} \mathrm{y}^{-1}\right)$ \\
\hline$[103]$ & 0.3 \\
\hline Duce and Duursma (1977) & $1.0-1.5$ \\
\hline Skopintsev (1971) & 1.8 \\
\hline Kempe (1979) & 1.9 \\
\hline Gerrels et al. (1975) & 2.0 \\
\hline Garrels and Mackenzie (1971) & 3.0 \\
\hline Mullholland and Watts (1982) & $3.0-4.0$ \\
\hline Meybeck (1981) & 4.0 \\
\hline Schlesinger and Melack (1981) & $3.7-4.1$ \\
\hline Stewart et al. (1978) & 5.0 \\
\hline$[105]$ & $2.0-10.0$ \\
\hline$[104]$ & 10.0 \\
\hline
\end{tabular}

Table 3: The global organic $C$ fluxes in some world rivers estimated from extrapolating the annual organic $\mathrm{C}$ flux data from several rivers (modified from Hope et al. [13]).

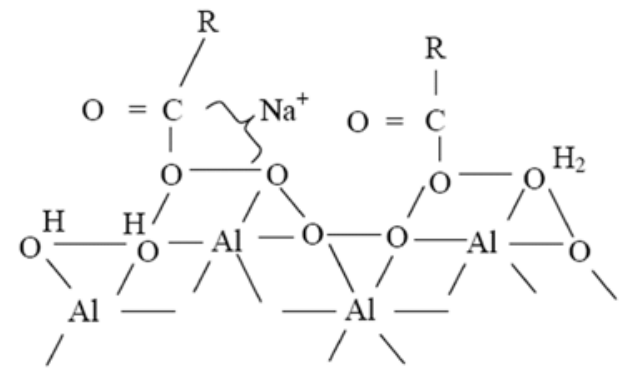

Figure 6: Ligand exchange mechanism for interaction of humic acids with hydrous aluminum oxide surfaces. Note: $R$ is the remainder of humic molecules which can also be associated with the surface, $\mathrm{O}$ is oxygen ion, $\mathrm{H}$ is hydrogen ion, $\mathrm{Na}$ is sodium ion and $\mathrm{C}$ is clay. (redrawn from Greenland [69]). 
and nanoparticle transport [117-119]. The impact of DOM on colloid mobility in saturated porous media was systematically examined in terms of pore water velocity and deposition kinetics [110,117]. Evaluations included the effects of mono- versus divalent cation concentrations, ionic strength on attachment efficiency, and charge reversal by organic matter adsorption $[110,120,121]$.

Arias-Estévez et al. [122] evaluated the sorption of PAHs to colloid dispersion of humic substances (HSs) in water. Notably, HSs can complicate many environmental pollutants such as PAHs, and the distribution of PAHs in the aqueous environment (free and bound to HSs) is important since it affects their stability and persistence. As reported by Arias-Estévez et al. [122], both steric hindrance and molecular interactions between the PAHs and the HSs' aromatic structures might play an important role in their binding reactions. The distribution of PAHs in colloidal dispersions of HSs in water (i.e., their stability-persistence and possible bioavailability in the natural aqueous environments) was controlled by the hydrophobicity and the water solubility of PAHs. Arias-Estévez et al. [122] also emphasized that adsorption of the different PAHs to HSs could be modeled in terms of both of these driving factors. In a river basin partially devoted to vineyards that are regularly treated with copper-based grapevine fungicides, Fernández-Calviño et al. [115] examined the copper $(\mathrm{Cu})$ levels in soils and river sediments. Soils differed relatively little regarding the distribution of $\mathrm{Cu}$ among various fractions; for instance, about $50 \%$ of total $\mathrm{Cu}$ content was generally bound to soil organic matter. Fernández-Calviño et al. [115] observed that the distribution of $\mathrm{Cu}$ in sediments was more heterogeneous. Sandy sediments had $\mathrm{Cu}$ distributions similar to those observed in soils; whereas in silty sediments with large inorganic colloids fractions, it was these amorphous colloids that bound the largest proportion of $\mathrm{Cu}$.

Systematic interaction and transport of DOM and colloids in unsaturated soils have not yet been studied in detail. Only limited studies have examined the effect of DOM and $\mathrm{pH}$ on colloid transport in unsaturated porous media and the effect of colloid transport in alkaline DOM rich conditions [111,123]. In general, interfaces with air in unsaturated porous media promote colloid retention and organic matter of hydrophobic character preferentially fractionates to the air-water interface [124]. Morales et al. [124] examined the effect of DOM on colloid characteristics through changes in surface potential, adsorbed layer thickness, and mass of adsorbed organic matter. They conducted transport experiments with tandem internal process visualization for key constituents of DOM, humic and fulvic acids at acidic, neutral and basic $\mathrm{pH}$ and two $\mathrm{CaCl}_{2}$ concentrations. Humic acid improved colloid transport significantly, while fluvic acid marginally affected transport [125]. Experiments with fluvic or no DOM promoted colloid retention at solid-water interfaces, while experiments with humic acid enhanced colloid retention at air-water interfaces due to partitioning of humic acid at the air-water interface and/or increased hydrophobic characteristics of humic-colloid complexes.

\section{Summary}

Dissolved organic matter plays an important role in many biogeochemical processes in soils and waters. It also plays an important role in elemental cycling and influences the cation leaching processes, mineral weathering and soil formation. The mobility of DOM in soils is controlled by its sorption to mineral surfaces. Several mechanisms i.e., anion sorption, ligand exchange, cation bridging, and physical adsorption, are postulated for describing DOM sorption on mineral surfaces. However, these mechanisms are not yet clearly understood and more research is needed to properly understand the processes associated with physical and chemical stabilization in soil. More efforts are needed to understand the steric effects of the silicate structure on orientation of organic absorbates. Equally important is to understand the effects due to structural and charge differences in clay, which may lead to different kinds of association with organic molecules. The degree of DOM sorption on mineral surfaces is dependent on $\mathrm{pH}$, average molecular weight of DOM, antecedent $\mathrm{C}$ content of soil, and surface soil characteristics. Little information is available on the relationship between mineralogy and the chemistry of adsorbed organic matter; particularly, the quantification and evaluation of the different interactions with mineral surfaces (e.g., impact of ligand exchange, cation bridges, hydrophobic interactions, complexation reactions) need to be addressed. It is generally assumed that adsorption diminishes the biodegradability of DOM. However, this has not yet been quantitatively established. Most of the research on sorptive protection is based on the results from laboratory experiments, which generally disregard changing hydrological conditions. More efforts are needed to investigate the biotic and abiotic controls on DOM concentration and fluxes in soil horizons especially by conducting field experiments. Such an effort should be made in conjunction with proper accounting of flow through the soil profile. The temperature dependence of these controls is also important and needs to be further investigated. Further research is necessary to bridge the information gap between the physicochemical changes of DOM-colloid complexes and soil interfaces and the effect that these systematic changes have on the transport and fate in unsaturated soils (i.e., the vadose zone). While most studies over the past several decades focus on DOM dynamics in forests and grasslands or stream ecosystems, little attention has been paid to quantifying DOM fluxes in human-dominated systems such as agricultural soils or soils of heavily populated basins.

The interactive effects of climate change and dissolved organic matter is another important area needing further efforts. Climate change may reduce DOM concentrations in aquatic ecosystems, thereby exacerbating UV effects by changing the amount and flowpaths of DOM from upland and wetland ecosystems. Therefore, there is a need to conduct experiments through a combination of landscape and hydrological analyses, biogeochemistry, photodegradation, and biodegradation of DOM. Such research will greatly enhance our knowledge of the interactive effects of climate change, landscape watershed attributes, and DOM on aquatic ecosystems.

\section{Acknowledgement}

Funding for the work was provided by New Mexico State University Agricultural Experiment Station and authors thank them for the support.

\section{References}

1. Herbert BE, Bertsch PM (1995) Characterization of dissolved and colloida organic matter in soil solution: A review. In: Kelly JM McFee WW (Eds.) Carbon forms and functions in forest soils, SSSA, Madison, WI, pp 63-88.

2. Zsolnay A (1996) Dissolved humus in soil waters. In: Piccolo A (Ed.) Humic substances in terrestrial ecosystems, Elsevier, Amsterdam, pp 171-223.

3. Dawson HJ, Ugolini FC, Hrutfiord BF, Zachara J (1978) Role of organics in the soil processes of a Podzol, central Cascades, Washington. Soil Sci 126 290-296.

4. Petersen L (1976) Podzols and podzolization. DSR Forlag, Kopenhagen.

5. Raulund-Rasmussen K, Borggaard OK, Hansen HCB, Olsson M (1998) Effect of natural soil solutes on weathering rates of soil minerals. Eur J Soil Sci 49 : 397-406.

6. Kalbitz K, Popp P, Geyer W, Hanschmann G (1997) $\beta-H C H$ mobilization in polluted wetland soils as influenced by dissolved organic matter. Sci Total Environ 204: 37-48. 
Citation: Deb SK, Shukla MK (2011) A Review of Dissolved Organic Matter Transport Processes Affecting Soil and Environmental Quality. J Environment Analytic Toxicol 1:106. doi:10.4172/2161-0525.1000106

7. Temminghoff EJM, Van der Zee SEATM, de Haan FAM (1997) Copper mobility in a copper-contaminated sandy soil as affected by $\mathrm{pH}$ and solid and dissolve organic matter. Environ Sci Technol 31: 1109-1115.

8. Kalbitz K, Kaiser K (2003) Ecological aspects of dissolved organic matter in soil: Preface. Geoderma 113: 177-178.

9. Carter CW, Suffet IH (1982) Binding of DDT to dissolve humic materials. Environ Sci Technol 16: 735-740.

10. Chiou CT, Malcolm RL, Brinton TI, Kile DE (1986) Water solubility enhancement of some organic pollutants and pesticides by dissolved humic and fulvic acids. Environ Sci Technol 20: 502-508.

11. Hassett JP, Milicic E (1985) Determination of equilibrium and rate constants for binding of a polychlorinated biphenyl congener by dissolved humic substances. Environ Sci Technol 19: 638-643.

12. Hasset JP (2006) Chemistry. Dissolved natural organic matter as a microreactor Science 311: 1723-1724.

13. Hope D, Billett MF, Cresser MS (1994) A review of the export of carbon in river waters: Fluxes and processes. Environ Pollut 84: 301-324.

14. Schimel DS (1995) Terrestrial ecosystems and the carbon cycle. Global Change Biol 1: 77-91.

15. Hedin LD, Armesto JJ, Johnson AH (1995) Patterns of nutrient loss from unpolluted old-growth temperate forest: Evaluation of biogeochemical theory. Ecology 76: 493-509.

16. McDowell WH, Wood T (1984) Podzolization: Soil processes control dissolved organic carbon concentrations in stream water. Soil Sci 137: 23-32.

17. Kalbitz K, Solinger S, Park J-H, Michalzik B, Matzner E (2000) Controls on dynamics of dissolved organic matter in soils: A review. Soil Sci 165: 277-304.

18. Thurman EM (1985) Humic substances in groundwater. In: Aiken GR, McKnight DM, Wershaw RL, MacCarthy P (Eds.) Humic substances in soil, sediment, and water, John Wiley, New York, pp 87-103.

19. Buffle J, Deladoey P, Zumstein J, Haerdi W (1982) Analysis and characterization of natural organic matters in fresh waters. I. study of analytical techniques. Schweiz Z Hydrol 44: 327-362.

20. Lam B, Baer A, Alaee M, Lefebvre B., Moser A, et al. (2007) Major structura components in freshwater dissolved organic matter. Environ Sci Technol 41: 8240-8247.

21. Hertkorn N, Benner R, Frommberger M, Schimitt-Kopplin P, Kaiser K, et al (2006) Characterization of a major refractory component of marine dissolved organic matter. Gechim Cosmochim Acta 70: 2990-3010.

22. McDowell WH, Likens GE (1988) Origin, composition, and flux of dissolved organic carbon in the Hubbard brook Valley. Ecol Monographs 58: 177-195.

23. Qualls RG, Haines BL (1991) Geochemistry of dissolved organic nutrients in water percolating through a forest ecosystem. Soil Sci Soc Am J 55: 1112 1123

24. Qualls RG, Haines BL, Swank WT (1991) Fluxes of dissolved organic nutrients and humic substances in a deciduous forest. Ecology 72: 254-266.

25. Guggenberger G, Zech W, Schulten H (1994) Formation and mobilization pathways of dissolved organic matter: Evidence from chemical structural studies of organic matter fractions in acid forest floor solutions. Organic Geochem 21: 51-66.

26. Park J-H, Kalbitz K, Matzner E (2002) Resource control on the production of dissolved organic carbon and nitrogen in a deciduous forest floor. Soil Bio Biochem 34: 813-822.

27. McDowell WH (2003) Dissolved organic matter in soils - future directions and unanswered questions. Geoderma 113: 179-186.

28. Schiff SL, Aravena R, Trumbore SE, Dillon PJ (1990) Dissolved organic carbon cycling in forested watersheds - a carbon isotope approach. Water Resour Res 26: 2949-2957.

29. Jones DL, Kielland K (2002) Soil amino acid turnover dominates the nitrogen flux in permafrost-dominated taiga forest soils. Soil Biol Biochem 34: 209-219.

30. Hornung M, Roda F, Langan SJ (1990) A review of small catchment studies in Western Europe producing hydrochemical budgets. Air Pollution Research Report 28, Commission of the European Communities, Belgium.
31. Naiman RJ, Sibert JR (1978) Transport of nutrients and carbon from the Nanaimo River to its estuary. Limnol Oceanogr 23: 1183-1193.

32. Mantoura RFC, Woodlands EMS (1983) Conservative behavior of dissolved organic carbon in the severn Estuary: chemical and geochemical implications. Geochim Cosmochim Acta 47: 1293-1309.

33. Naiman RJ (1982) Characteriostic of sediment and organic carbon export from pristine boral forest watersheds. Canadian J Fisheries Aquatic Sci 39 1699-1718.

34. Minshall GW, Petersen RC, Cummins KW, Bott TL, Sedell JR, et al. (1983) Interbiome comparison of stream ecosystem dynamics. Ecol Monographs $53: 1-25$

35. Naiman, RJ, Melillio JM, Lock MA, Ford TE, Rice SR (1987) Longitudina patterns of ecosystem processes and community structure in a subarctic rive continuum. Ecology 68: 1139-1156.

36. Reid JM, MacLeod DA, Cresser MS (1981) Factors affecting the chemistry of precipitation and river water in an upland catchment. J Hydrol 50: 129-145.

37. McDowell WH, Zsolnay A, Aitkenhead-Peterson JA, Gregorich EG, Jones $\mathrm{DL}$, et al. (2006) A comparison of methods to determine the biodegradable dissolved organic carbon from different terrestrial sources. Soil Biol Biochem 38: 1933-1942.

38. Moore TR (1989) Dynamics of dissolved organic carbon in forested and disturbed catchments, Westland, New Zealand: 1. Maimai. Water Resour Res 25: $1321-1330$.

39. Dosskey MG, Bertsch PM (1997) Transport of dissolved organic matter through a sandy forest soil. Soil Sci Soc Am J 61: 920-927.

40. Buckingham S, Tipping E, Hamilton-Taylor J (2008) Dissolved organic carbon in soil solutions: A comparison of collection methods. Soil Use and Manage 24: 29-36.

41. Chantigny $\mathrm{MH}$, Angers DA, Kaiser K, Kalbitz K (2008) Extraction and characterization of dissolved Organic matter. In: Carter MR, Gregorich EG (Eds.) Soil Sampling and Methods of Analysis, Second edition, CRC Press Taylor \& Francis, Boca Raton, FL, Chapter 48.

42. Zsolnay A (2003) Dissolved organic matter: artefacts, definitions, and functions. Geoderma 113: 187-209.

43. García-Falcón MS, Pérez-Lamela C, Simal-Gándara J (2004) Strategies for the extraction of free and bound polycyclic aromatic hydrocarbons in run-off waters rich in organic matter. Anal Chim Acta 508: 177-183.

44. Rey-Salgueiro L, Pontevedra-Pombal X, Álvarez-Casas M, Martínez-Carballo E, García-Falcón MS, Simal-Gándara J (2009) Comparative performance of extraction strategies for polycyclic aromatic hydrocarbons in peats. J Chromatography 1216: 5235-5241.

45. Linkens GE, Edgerton ES, Galloway JN (1982) The composition and deposition of organic carbon in precipitation. Tellus 35: 16-24

46. Schreiber JD, Duffy PD (1982) Organic carbon and oxygen demand relationships in stormflow from southern pine watersheds. Soil Sci Soc Am J 46: 142-148.

47. Likens GE, Bormann FH, Pierce RS, Eaton JS, Johnson NM (1977) Biogeochemistry of a forested ecosystem. Springer-Verlag, New York.

48. Galloway JN, Likens GE, Keene WC, Miller JM (1982) Composition of precipitation in remote areas of the world. J Geophys Res 87: 8771-8786.

49. Fernandez IJ, Kosian PA (1987) Soil air carbon dioxide concentrations in New England spruce-fir forest. Soil Sci Soc Am J 51: 261-263.

50. Moore TR (1987) An assessment of a simple spectrophotometric method fo the determination of dissolved organic carbon in freshwaters. New Zealand Marine Freshwater Res 21: 585-589.

51. Grieve IC (1990) Seasonal hydrological and management factors controlling dissolved organic carbon concentrations in the loch fleet catchments, Southwest Scotland. Hydrol Process 4: 231-239.

52. Skiba U, Cresser MS (1991) Seasonal changes in soil atmospheric $\mathrm{CO}_{2}$ concentrations in two upland catchments and associated changes in river wate chemistry. Chem Ecol 5: 217-225.

53. Mattsson T, Kortelainen P, Laubel A, Evans D, Pujo-Pay M, et al. (2009) Export of dissolved organic matter in relation to land use along a European climatic gradient. Sci Total Environ 407: 1967-1976. 
Citation: Deb SK, Shukla MK (2011) A Review of Dissolved Organic Matter Transport Processes Affecting Soil and Environmental Quality. J Environment Analytic Toxicol 1:106. doi:10.4172/2161-0525.1000106

Page 10 of 11

54. Gregory RJ, Walling WE (1973) Drainage basins form and processes: a geomorphological approach. John Wiley, New York.

55. Lotspeich FB (1980) Watersheds as the basic ecosystem: this conceptua framework provides a basis for a natural classification system. Water Resour Bull 16: 581-586.

56. Harvey JW, Wagner BJ (2000) Quantifying hydrologic interactions between streams and their subsurface hyporheic zones. In: Jones JB, Mulholland PJ (Eds.) Streams and groundwaters, Academic Press, San Diego, CA, pp 3-44.

57. Arias-Estévez M, López-Periago E, Martínez-Carballo E, Simal-Gándara J, Mejuto J-C, García-Río L (2008) The mobility and degradation of pesticides in soils and the pollution of groundwater resources. Agric Ecosyst Environ 123: 247-260.

58. Dai KH, David MB, Vance GF (1996) Characterization of solid and dissolved carbon in a spruce-fir Spodosol. Biogeochem 15: 1-19.

59. Guggenberger G, Kaiser K, Zech W (1998) Mobilization and immobilization of dissolved organic matter in forest soils. Z Pflanzernaehr Bodenkd 161: 401408.

60. Cronan CS, Aiken GR (1985) Chemistry and transport of soluble humic substances in forested watersheds of the Adirondack Park, New York. Geochim Cosmochim Acta 49: 1697-1705.

61. Sollins P, McCorison FM (1981) Nitrogen and carbon solution chemistry of an old growth coniferous forest watershed before and after cutting. Water Resour Res 17: 1409-1418.

62. Wallis PM, Hynes HBN, Telang SA (1981) The importance of groundwater in the transportation of allochthonous dissolved organic carbon to the streams draining a small mountain basin. Hydrobiologia 79: 77-90.

63. Hornung M, Stevens PA, Reynolds B (1986) The impact of pasture management on the soil solution chemistry of some stagnopodzols in mid-wales. Soil Use Manage 2: 18-26.

64. Matzner E (1984) Annual rates of deposition of polycyclic aromatic hydrocarbons in different forest ecosystems. Water Air Soil Pollut 21: 425-434.

65. Wilcke W, Zech W, Kobza J (1996) PAH pools in soils along a PAH deposition gradient. Environ Pollut 92: 307-313.

66. García-Falcón MS, Sotoา-González B, Simal-Gándara J (2006) Evolution of the Concentrations of polycyclic aromatic hydrocarbons in burnt woodland soils. Environ Sci Technol 40: 759-763.

67. Tipping E (1998). Modelling the properties and behavior of dissolved organic matter in soils. Mitteilgn Dtsch Bodenk Gesellsch 87: 237-252.

68. Leenheer JA (1980) Study of sorption of complex organic solute mixtures on sediments by dissolved organic carbon fractionation analysis. In: Baker RA (Ed.) Contaminants and sediments: Analysis, chemistry, and biology, Vol 2 Ann Harbor Sci Publ, Ann Arbor, MI, pp 267-278.

69. Greenland DJ (1971) Interactions between humic and fulvic acids and clay. Soil Sci 111: 34-39.

70. Sibanda HM, Young, SD (1986) Competitive adsorption of humus acids and phosphate on goethite, gibbsite and two tropical soils. J Soil Sci 37: 197-204.

71. Jardine PM, Weber NL, McCarthy JF (1989) Mechanisms of dissolved organic carbon adsorption on soil. Soil Sci Soc Am J 53: 1378-1385.

72. Fiebig DM, Lock MA, Neal C (1990) Soil water in the riparian zone as a source of carbon for a headwater stream. J Hydrol 116: 217-237.

73. Currie WS, Aber JD, McDowell WH, Boone RD, Magill AH (1996) Vertical transport of dissolved organic $\mathrm{C}$ and $\mathrm{N}$ under long-term $\mathrm{N}$ amendements in pine and hardwood forests. Biogeochem 35: 471-505.

74. Guggenberger G, Kaiser K (2003) Dissolved organic matter in soil: Challenging the paradigm of sorptive preservation. Geoderma 113: 293-310.

75. Davis JA (1980) Adsorption of natural organic matter from freshwater environments by aluminum oxide. In: Baker RA (Ed.) Contaminants and sediments: Analysis, chemistry, and biology, Vol 2, Ann Arbor Sci Publ, Ann Arbor, MI, pp 179-305.

76. Schwertmann U (1966) Inhibitory effect of soil organic matter on the crystallization of amorphous ferric hydroxide. Nature 212: 645-646.

77. Davis JA (1982) Adsorption of natural dissolved organic matter at oxide/water interface. Geochim Cosmochim Acta 46: 2381-2393.
78. Wershaw RL, Pinckney DJ (1980) Isolation and characterization of clay humus complexes. In: Baker RA (Ed.) Contaminants and sediments: Analysis, chemistry, and biology, Vol 2, Ann Arbor Sci Publ, Ann Arbor, MI, pp 207-219.

79. Tipping $E$ (1981) Adsorption by goethite $(\alpha-F e O O H)$ of humic substances from three different lakes. Chem Geol 33: 81-89.

80. Vance GF, David MB (1992) Dissolved organic carbon and sulfate sorption by spodosol mineral horizons. Soil Sci 154: 136-144.

81. Ho CH, Miller NH (1985) Effect of humic acid on uranium uptake by hematite particles. J Colloid Interface Sci 106: 281-288.

82. Burke IC, Yonker CM, Parton WJ, Cole CV, Flach K, Schimel DS (1989) Texture, climatic and cultivation effects on soil organic matter content in U.S grassland soils. Soil Sci Soc Am J 53: 800-805.

83. Mayer LM (1994a) Relationships between mineral surfaces and organic carbon concentrations in soils and sediments. Chemical Geology 114: 347-363.

84. Mayer LM (1994b) Surface area control of organic carbon accumulation in continental shelf sediments. Geochim Cosmochim Acta 58: 1271-1284.

85. Mayer LM, Macko SA, Cammen L (1988) Provenance, concentrations and nature of sedimentary organic nitrogen in the Gulf of Maine. Mar Chem 25 : 291-304.

86. Parfitt RL, Fraser AR, Farmer VC (1977) Adsorption of hydrous oxides III. Fulvic acid and humic acid on goethite, gibbsite and imogolite. J Soil Sci 28: 289-296.

87. Inoue T, Wada K (1968) Adsorption of humified clover extracts by various clays. Int. Congr Soil Sci Trans. 9: 289-298.

88. Kalbitz K, Solinger S, Rethemeyer J, Matzner E (2005) Stabilization of dissolved organic matter by sorption to mineral soil. Soil Biol Biochem 37: 1319-1331.

89. Kaiser K, Guggenberger G (2003) Mineral surfaces and soil organic matter. Eur J Soil Sci 54: 219-236.

90. Kodama, H, Schintzer M (1974) Adsorption of fulvic acids by non-expanding clay minerals. Trans 10 th Int Congr Soil Sci (Moscow) 11: 51-56.

91. Pateiro-Moure M, Pérez-Novo C, Arias-Estévez M, Rial-Otero R, SimalGándara J (2009) Effect of organic matter and iron oxides on quaternary herbicide sorption-desorption in vineyard-devoted soils. J Colloid Interface Sci 333: $431-438$

92. Hingston FJ, Atkinson RJ, Posner AM, Quirk JP (1967) Specific adsorption of anions. Nature 215: 1459-1461.

93. Somasundaram P, Fuerstenau DW (1966) Mechanisms of alkyl sulfonate adsorption at the alumina-water interface. J Phys Chem 70: 90-96.

94. Kaiser K, Zech W (1998) Soil dissolved organic matter sorption as influenced by organic and sesquioxide coatings and sorbed sulfate. Soil Sci Soc Am J 62 129-136.

95. Vance GF, David MB (1989) Effect of acid treatment on the leachate chemistry of a New England spodosol: Importance of the B horizon on dissolved organic carbon retention. Soil Sci Soc Am J 53: 1242-1247.

96. David MB, Zech W (1990) Adsorption of dissolved organic carbon and sulfate by acid forest soils in the Fichtelgebirge. FRG Z Pflanzenernaehr Bodenkd 153 379-384.

97. Wildensee F, Baham J (1988) Surface complexation of sulfate and protons by kaolinite: non-stoichiometric exchange. In: Agronomy abstracts, ASA, Madison, WI, pp 207.

98. Gobran GR, Nielsen SI (1988) Effects of forest floor leachate on sulfate retention in a Spodosol soil. J Environ Qual 17: 235-239.

99. Mortland MM (1986) Mechanisms of adsorption of nonhumic organic species by clays. In: Huang PM, Schnitzer M (Eds.) Interactions of soil minerals with natural organics and microbes. Soil Sci Soc Am Special Publ Number 17 SSSA, Madison, WI, pp 59-76.

100. Mortland MM, Raman KV (1968) Surface acidity of smectites in relation to hydration, exchange cation, and structure. Clays Clay Minerals 16: 393-398.

101.Mortland MM (1966) Urea complexes with montmorillonites: An infrared adsorption study. Clay Minerals 6: 143-156.

102. McKee BA (2003) RiOMar: The transport, transformation and fate of carbon in River-dominated Ocean Margins. Report of the RiOMar Workshop, 1-3 Novemeber 2001, Tulane University, New Orleans, LA. 
Citation: Deb SK, Shukla MK (2011) A Review of Dissolved Organic Matter Transport Processes Affecting Soil and Environmental Quality. J Environment Analytic Toxicol 1:106. doi:10.4172/2161-0525.1000106

Page 11 of 11

103. Williams PM (1971) The distribution and cycling of organic matter in the ocean In: Faust SJ, Hunter JV (Eds.) Organic compounds in aquatic environments, Marcel Dekker, New York, pp 145-163.

104. Richey JE, Brock JT, Naiman RJ, Wissman RC, Stallard RF (1980) Organic carbon: oxidation and transport in the Amazon river. Science 207: 1348-1350.

105. Reiners WA (1973) Terrestrial detritus and carbon cycle. Brookhaven Symp Biol 303-327.

106. Houghton RA, Hobbie JE, Melillo JM, Moore B, Peterson BJ, et al. (1983) Changes in the carbon content of terrestrial biota and soils between 1860 and 1980: A net release of $\mathrm{CO}_{2}$ to the atmosphere. Ecolog Monographs 53: 235-262.

107. Ludwig W, Amiotte-Suchet P, Munhoven G, Probst JL (1998) Atmospheric CO2 consumption by continental erosion: present-day controls and implications for the last glacial maximum. Global Planetary Change 17: 107-120.

108. Watson RT, Zinyowerea MC, Moss RH (Eds.) (1996) Climate change 1995 Impacts, adaptations and mitigation of climate change, Scientific-Technical Analyses. Contribution of Working Group II to the Second Assessment Report of the Intergovernmental Panel on Climate Change (IPCC), Cambridge University Press.

109. Flury M, Qiu HX (2008) Modeling colloid-facilitated contaminant transport in the vadose zone. Vadose Zone J 7: 682 -697.

110. Jaisi DP, Saleh NB, Blake RE, Elimelech M (2008) Transport of single-walled carbon nanotubes in porous media: Filtration mechanisms and reversibility. Environ Sci Technol 42: 8317-8323.

111. Tang $X Y$, Weisbrod $N$ (2009) Colloid-facilitated transport of lead in natural discrete fractures. Environ Pollut 157: 2266-2274.

112. Abudalo RA, Ryan JN, Harvey RW, Metge DW, Landkamer L (2010) Influence of organic matter on the transport of Cryptosporidium parvum oocysts in a ferric oxyhydroxide-coated quartz sand saturated porous medium. Water Res 44: 1104-1113.

113. Arias-Estévez M, Soto-González B, López-Periago E, Cancho-Grande B Simal-Gándara J (2005) Atrazine sorption dynamics in acid-surface soils. Bull Environ Contam Toxicol 75: 264-271.

114. Arias M, Torrente AC, López E, Soto B, Simal-Gándara J (2005) Adsorption- desorption dynamics of cyprodinil and fludioxonil in vineyard soils. J Agric Food Chem 53: 5675-5681.

115. Fernández-Calviño D, Rodríguez-Suárez JA, López-Periago E, AriasEstévez M, Simal-Gándara J (2008) Copper content of soils and river sediments in a winegrowing area, and its distribution among soil or sediment components. Geoderma 145: 91-97.

116. Bermúdez-Couso A, Fernández-Calviño D, Pateiro-Moure M, Nóvoa-Muñoz JC, Simal-Gándara J, Arias-Estévez M (2011) Adsorption and desorption kinetics of carbofuran in acid soils. J Hazardous Mat 190: 159-167.

117. Akbour RA, Douch J, Hamdani M, Schmitz P (2002) Transport of kaolinite colloids through quartz sand: influence of humic acid, $\mathrm{Ca}^{2+}$, and trace metals. J Colloid Inter Sci 253: 1-8.

118. Breiner JM, Anderson MA, Tom HWK, Graham RC (2006) Properties of surfacemodified colloidal particles. Clays Clay Minerals 54: 12-24.

119. Chen KL, Mylon SE, Elimelech M (2006) Aggregation kinetics of alginatecoated hematite nanoparticles in monovalent and divalent electrolytes. Environ Sci Technol 40: 1516-1523.

120. Kretzschmar R, Sticher H (1997) Transport of humic-coated iron oxide colloids in a sandy soil: influence of $\mathrm{Ca}^{2+}$ and trace metals. Environ Sci Technol 31 : 3497-3504

121. Franchi A, O'Melia CR (2003) Effects of natural organic matter and solution chemistry on the deposition and reentrainment of colloids in porous media. Environ Sci Technol 37: 1122-1129.

122. Arias-Estévez M, Fernández-Gándara, García-Falcón MS, García-Río L, Mejuto JC, Simal-Gándara J (2007) Sorption of PAHs to colloid dispersions of humic substances in water. Bull Environ Contam Toxicol 79: 251-254.

123. Harvey RW, Metge DW, Barber LB, Aiken GR (2010) Effects of altered groundwater chemistry upon the $\mathrm{pH}$-dependency and magnitude of bacterial attachment during transport within an organically contaminated sandy aquifer. Water Res 44: 1062-1071.

124. Morales VL, Zhang W, Gao B, Lion LW, Bisogni Jr JJ, et al. (2011) Impact of dissolved organic matter on colloid transport in the vadose zone: Deterministic approximation of transport deposition coefficients from polymeric coating characteristics. Water Res 45: 1691-1701.

125. Neff JC, Asner GP (2001) Dossolved organic carbon in terrestrial ecosystems: Synthesis and a model. Ecosystems 4: 29-48. 